\title{
"CAXI XANATH" BASE DE DATOS DE LA COLECCIÓN DE ORQUÍDEAS DEL JARDÍN BOTÁNICO CLAVIJERO
}

\author{
Philip J.B Rewster \& L.I. Maricruz Peredo Nava \\ Instituto de Ecología, A.C., Xalapa, Veracruz, México
}

La importancia de documentar las colecciones de plantas en los jardines botánicos es esencial para realizar estudios sobre ellas. De los 51 jardines botánicos de México, el Jardín Botánico Clavijero (JBC), es el único ubicado en Bosque Mesófilo de Montaña (BMM). La ventaja de contar con una base de datos de la colección del jardín botánico facilita la investigación, educación y conservación. Se presenta CAXI_XANATH (Flor negra en lengua totonaca de Vanilla planifolia), una base de datos diseñada en Access 2000 que almacena información de ejemplares vivos depositados en la Colección de Orquídeas del JBC. Actualmente CAXI_XANATH contiene cerca de 1300 registros (ca. 140 especies) de 18 Estados de la República, e incluye información curatorial, geográfica, taxonómica, referencias bibliográficas, imágenes, técnicas empleadas y estudios de cultivo, además de actuar como una guía de identificación enfocada a las especies de BMM de la región. Tal información servirá para la publicación de un libro y CD-ROM.

Antecedentes. La colección de orquídeas del JBC es una de las más importantes de los jardines botánicos de México. Eso se debe principalmente al tamaño de la colección y a que la mayor parte de sus ejemplos son colectas locales del BMM, uno de los hábitats de mayor riqueza pero dentro de los más amenazados del país. En él se encuentra una alta concentración de diversidad de orquídeas. El hecho de que el JBC es el único jardín botánico de México ubicado en BMM con, tal vez la única colección documentada de orquídeas de la región, destaca su importancia actual y futuro potencial.

Problemática. Reconociendo la diversidad de especies en la colección, se detectó cierta problemática en la falta de conocimiento de detalles hortícolas, ya que el almacenamiento de los registros en una base de datos ya existente, estaba limitada solo a los datos de colecta. Otro de los problemas ha sido la falta de actualización de información en la base de datos, lo que provoca que exista una gran inconsistencia entre los registros y estado actual de la colección; identificación, ubicación, pérdida de material.

Base de datos Caxi Xanath. Es por esto que nace CAXI_XANATH, una base de datos diseñada para administrar información sobre la colección de orquídeas. En su primera fase se dirige más a quienes tienen mayor contacto e interés en la colección, por ejemplo los jardineros del jardín botánico y el público en general. Almacena tanto datos de colecta como información hortícola, por ejemplo la aplicación de sustratos, riego y fertilizantes y control de luz, temperatura y humedad, además de la identificación de plagas y enfermedades y su control.

Para lograr la identificación correcta de cada especie, se cuenta con una característica vital en la base de datos que es la presentación de imágenes de cada registro de la colección y la información taxonómica, de distribución y habitat que le corresponde.

Se emplean tres niveles taxonómicos (género, especie, infraespecie) incluyendo también sinonimia y nombres vernaculares. Se basa sobre la clasificación de Dressler (1993) y sigue las abreviaciones de los autores de Brummitt \& Powell (1992).

Como información adicional, se pretende conservar referencia bibliográfica de la descripción de las especie, así como referencia a la bibliografía particular.

Otros detalles que incluye son notas sobre la aplicación de métodos de polinización y la fenología.

Estructura. El modelo de base de datos CAXI XANATH utiliza un modelo de datos relacional constituido por 26 tablas relacionales, las cuales fueron creadas a partir del manejador de bases de datos Access 2000. 


\begin{tabular}{lr}
\hline Pais & Número registros \\
\hline México (18 Estados) & 1281 \\
Otros países & 20 \\
\hline & \\
\hline Tipo de Vegetación & Número registros \\
\hline No definida & 788 \\
Bosque mesófilo de montaña & 197 \\
Bosque tropical perennifolio & 135 \\
Bosque de Quercus & 115 \\
Bosque tropical caducifolio & 26 \\
Bosque de coníferas & 21 \\
Bosque tropical subcaducifolio & 15 \\
Pastizal & 3 \\
Palmar & 1 \\
\hline
\end{tabular}

Cuadro 1. Registros incluidos en la base de datos, con su procedencia geográfica y ecológica.

La incorporación y actualización de información se realiza a través de sencillos formularios de captura. Los datos almacenados en las tablas pueden ser extraídos con consultas y visualizados en informes o formularios. Los datos pueden ser exportados a formatos como Excel, Lotus, Paradox, Dbase, documentos html, archivos de texto, archivos en formato RTF, SQL, entre otros.

\begin{tabular}{lr}
\hline Veracruz & Número registros \\
\hline Géneros & 85 \\
Especies & 193 \\
\hline
\end{tabular}

Cuadro 2. Registros del Estado de Veracruz.

Actualmente la base de datos alberga un poco más de 1300 registros (ca. 140 especies) de 18 Estados de la República, distribuidos de la manera indicada en el Cuadro 1.

Para México, es el estado de Veracruz el más representativo, ya que contamos con 1051 registros (Cuadro 2).

Conclusión. Para contribuir en el cumplimiento de los objetivos de la misión del JBC (investigación, educación y conservación), la base de datos de la colección de orquídeas tendrá un papel inicial importante en el uso de su información por parte del personal del jardín (información completa) y del público en general (información restringida), esto último se pretende presentar en forma de un manual, CD-ROM y página web.

Como parte del seguimiento a este proyecto se continuará con el proceso de alimentación a la base de datos con información técnica que servirá de apoyo a la comunidad científica.

Philip J. Brewster. Realizó estudios de horticultura en Merrist Wood Agricultural College, Inglaterra. Del 1985 a 1996 trabajó como horticultor botánico en los Royal Botanic Gardens, Kew donde estuvo encargado de varias colecciones vivas en el departamento de plantas tropicales. Durante ese tiempo realizó expediciones a España (principalmente Las Islas Canarias) y Colombia. Desde 1996 colabora en el Jardín Botánico Clavijero del Instituto de Ecología, México como responsable de las áreas públicas. A partir del 2000 es encargado de la colección de orquídeas participando en cursos y talleres como miembro de la Asociación de Orquideología de México. 